\title{
Wpływ mikrotekstury i procesu kwasowania skały na jej parametry zbiornikowe: studium przypadku piaskowców krośnieńskich z rejonu Dwernika, Bieszczady
}

\author{
Piotr Jan Strzelecki ${ }^{1}$, Marek Leszek Solecki
}

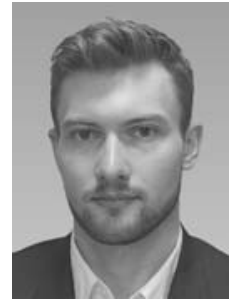

P.J. Strzelecki

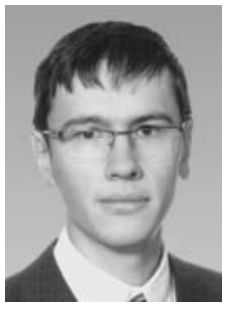

M.L. Solecki

The influence of rock microtexture and acidizing on reservoir properties: a case study of the Krosno Sandstones from Dwernik, Bieszczady Mts. Prz. Geol., 69: 454-457; doi: $10.7306 / 2021.30$

A b s t r a c t. The paper briefly describes $3 D$ variability of reservoir properties, such as porosity and permeability at a micro-scale in reference to the directionality of rock microtexture and the occurrence of a deformation band. The study was conducted on the sample of the coarse-grained Krosno Sandstones with a deformation band after treatment with hydrochloric acid. Spot measurements of permeability using a portable air minipermeameter and porosity using $X$-ray computed microtomography were made. The local porosity within the sample ranges from 1.38 to $2.70 \%$, whereas the permeability varies from 7.5 to $14.5 \mathrm{mD}$. The anisotropy of permeability within the sample is related to the orientation of pores. The highest permeability values are observed in the direction parallel to the largest elongation of pores. The deformation band shows higher permeability values in comparison to the undeformed part of the sample.

Keywords: reservoir quality, porosity, permeability, texture, deformation band

Porowatość i przepuszczalność należa do podstawowych parametrów opisujących właściwości zbiornikowe skał. Parametry te w dużym stopniu zależą od tekstury skały (Beard,Weyl, 1973), na którą lokalnie ma wpływ obecność struktur tektonicznych. Przykładem takich struktur są wstęgi deformacyjne. Występują one dość powszechnie w obrębie silikoklastycznych skał zbiornikowych (por. Fossen i in., 2018). Ich występowanie znacząco przyczynia się do zmiany parametrów zbiornikowych skały, stąd też uwzględnia się je w modelowaniach złożowych (np. Qu, Tveranger, 2017). Wstęgi deformacyjne zaobserwowano w piaskowcach krośnieńskich w bieszczadzkiej części płaszczowiny śląskiej (ryc. 1). Piaskowce krośnieńskie stanowią tu regionalny poziom skał zbiornikowych.

Dzięki rozwojowi technik badawczych i aparatury pomiarowej istnieje możliwość trójwymiarowej analizy zmienności właściwości zbiornikowych w skali mikroskopowej, co umożliwia precyzyjne określenie wpływu tekstury skały na jej parametry filtracyjne. Dlatego też piaskowce krośnieńskie, pocięte wstęgami deformacyjnymi, wydają się być doskonałym obiektem do przeprowadzenia tego typu badań. Określenie przyczyny zmienności parametrów zbiornikowych piaskowców krośnieńskich w mikroskali jest głównym celem niniejszej pracy.

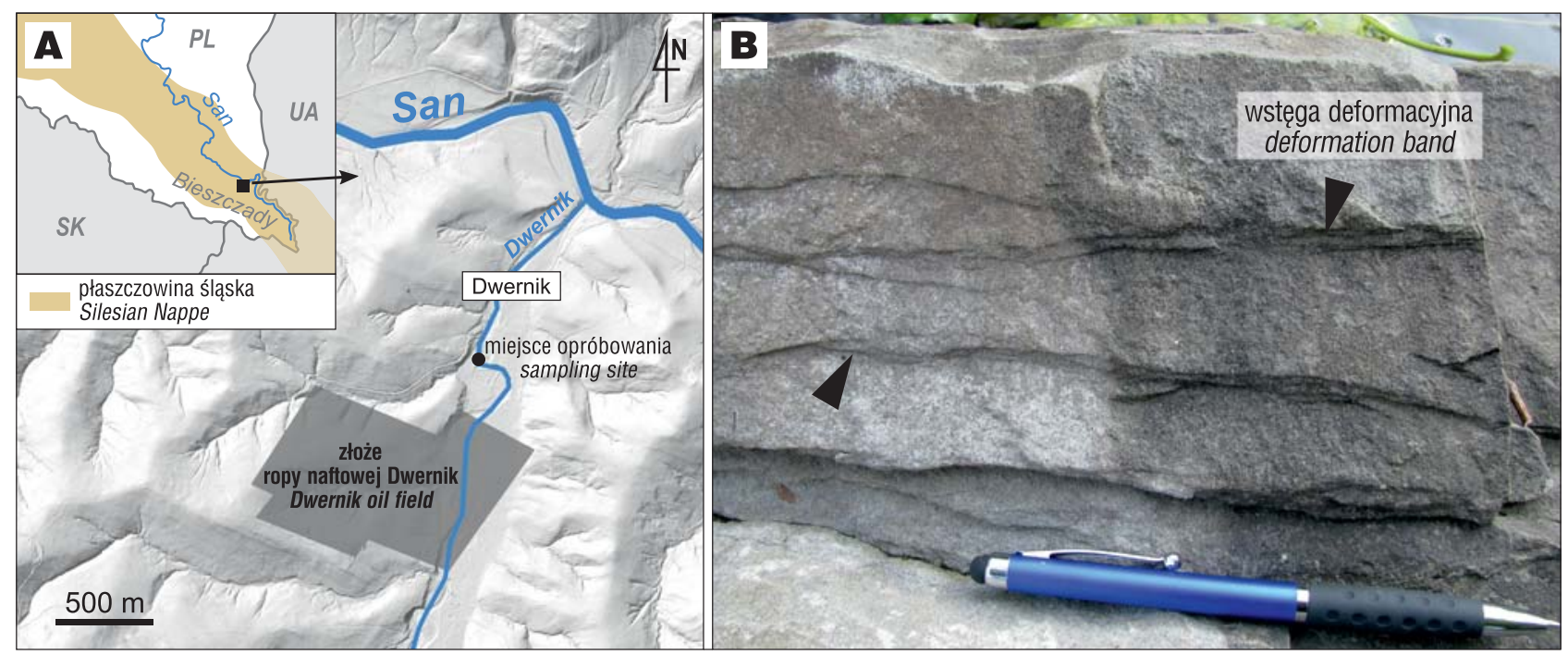

Ryc. 1. A-mapa lokalizacyjna obróbowanego odsłonięcia $\left(49.2106^{\circ} \mathrm{N}, 22.6246^{\circ} \mathrm{N}\right), \mathbf{B}$-zdjęcie odsłonięcia piaskowców krośnieńskich z widocznymi wstęgami deformacyjnymi

Fig. 1. A - location map of sampling sites $\left(49.2106^{\circ} \mathrm{N}, 22.6246^{\circ} \mathrm{N}\right), \mathbf{B}$ - outcrop of the Krosno sandstones with deformation bands

\footnotetext{
${ }^{1}$ AGH Akademia Górniczo-Hutnicza im. Stanisława Staszica w Krakowie, Wydział Geologii, Geofizyki i Ochrony Środowiska, al. Mickiewicza 30, 30-059 Kraków; piotrjanstrzelecki@gmail.com

${ }^{2}$ AGH Akademia Górniczo-Hutnicza im. Stanisława Staszica w Krakowie, Wydział Wiertnictwa, Nafty i Gazu, al. Mickiewicza 30, 30-059 Kraków.
} 


\section{MATERIAŁ I METODY}

Badanym materiałem jest próbka gruboziarnistych piaskowców krośnieńskich pobrana z naturalnego odsłonięcia w miejscowości Dwernik (Bieszczady), zlokalizowanego w sąsiedztwie złoża ropy naftowej (ryc. 1A). Próbka w kształcie półwalca, o wysokości 1,2 cm i promieniu $1,8 \mathrm{~cm}$, została poddana procesowi kwasowania w celu usunięcia składników zbudowanych z węglanu wapnia oraz uwidocznienia cech teksturalnych skały. Kwasowanie przeprowadzono z zastosowaniem $15 \%$ roztworu kwasu solnego, w którym próbka pozostawała zanurzona przez 48 h. Próbka przed i po kwasowaniu została przebadana z wykorzystaniem porozymetrii helowej oraz mikrotomografii rentgenowskiej $(\mu \mathrm{CT}) \mathrm{w}$ celu określenia wielkości porowatości i zobrazowania przestrzeni porowej skały (ryc. 2).

Uzyskany obraz $\mu \mathrm{CT}$, o rozdzielczości $12 \mu \mathrm{m}$, został poddany cyfrowej analizie obrazu, co umożliwiło pomiar porowatości oraz orientacji powstałych po kwasowaniu porów, nawiązujących do tekstury skały w trójwymiarze. W obliczeniach uwzględniono pory, które nie dochodziły do powierzchni próbki. Do porów zostały dopasowane elipsoidy, a ich przestrzenna orientacja opisana osiami: a, b, c (por. Strzelecki i in., 2019, 2021). Orientacje osi elipsoid zostały zestawione na diagramach rozetowych w lokalnym układzie odniesienia. Pomiar orientacji porów został przeprowadzony na 5 tys. największych $\mathrm{z}$ nich, o kształtach nawiązujących do zarysu ziaren lub kryształów cementów. Na próbce skalnej wykonano punktowe pomiary przepuszczalności przy użyciu przepuszczalnościomierza powietrznego TinyPerm 3 firmy New England Research Inc, które polegają na dociśnięciu gumowej dyszy o wewnętrznej średnicy $8 \mathrm{~mm}$ do próbki skalnej. Następnie w urządzeniu jest wytwarzana próżnia, która zanika wraz z dopływem powietrza przepuszczonego przez przestrzeń skały. Przyrząd monitoruje objętość dopływającego powietrza i zanik próżni, na podstawie których oblicza przepuszczalność (por. Filomena i in., 2014). Wykonano 9 pomiarów przepuszczalności w kierunku prostopadłym i równoległym do podstawy próbki (ryc. 3A) oraz 9 pomiarów porowatości obejmujących przestrzeń skały w miejscach pomiaru przepuszczalności. Wyniki zestawiono na wykresach punktowych.

\section{WYNIKI}

W obrębie próbki skalnej jest widoczna mikrostruktura deformacyjna w postaci wstęgi deformacyjnej (ryc. 3B). Wstęga przebiega prostopadle do półcylindrycznej podstawy próbki. W obrębie jądra wstęgi obserwuje się wydłużone pory w postaci mikroszczelin. Pory te jako jedyne były obserwowane przed zabiegiem kwasowania (ryc. 2A). Zabieg kwasowania doprowadził do usunięcia składników węglanowych z najbardziej zewnętrznej strefy analizowanej próbki (ryc. 2B). Badania porozymteryczne wykazały wzrost porowatości próbki po kwasowaniu z 2,1 do 3,8\%. Zasięg strefy rozpuszczonej sięga $1 \mathrm{~mm}$ w głąb skały. W przypadku wstęgi deformacyjnej zasięg penetracji kwasu jest lokalnie większy, a niektóre widoczne pory są wydłużone i nawiązują do przebiegu wstęgi (ryc. 2B). Obserwowana na obrazie $\mu \mathrm{CT}$ strefa zmian związana ze wstęgą deformacyjną osiagga szerokość $8 \mathrm{~mm}$ i charakteryzuje się mniejszymi porami w stosunku do pozostałej niezdeformowanej części skały (ryc. 3B). Przestrzenne rozmieszczenie porów jest uzależnione od matrycy skalnej, średnia odległość pomiędzy porami wynosi $0,61 \mathrm{~mm}$, co w przybliżeniu wskazuje na średnią średnicę ziaren badanej próbki oraz jej gruboziarnistą teksturę. Obserwuje się pewien stopień kierunkowości wykształcenia przestrzeni porowej (ryc. 4). Dominujący kierunek ułożenia osi elipsoidy a i c jest obserwowany w kierunku o przebiegu zbliżonym do W-E (w lokalnym układzie odniesienia). Natomiast w przypadku osi b jest to kierunek prostopadły, o przebiegu N-S. Maksymalna różnica pomiędzy kierunkiem dominującym a pozostałymi kierunkami waha się

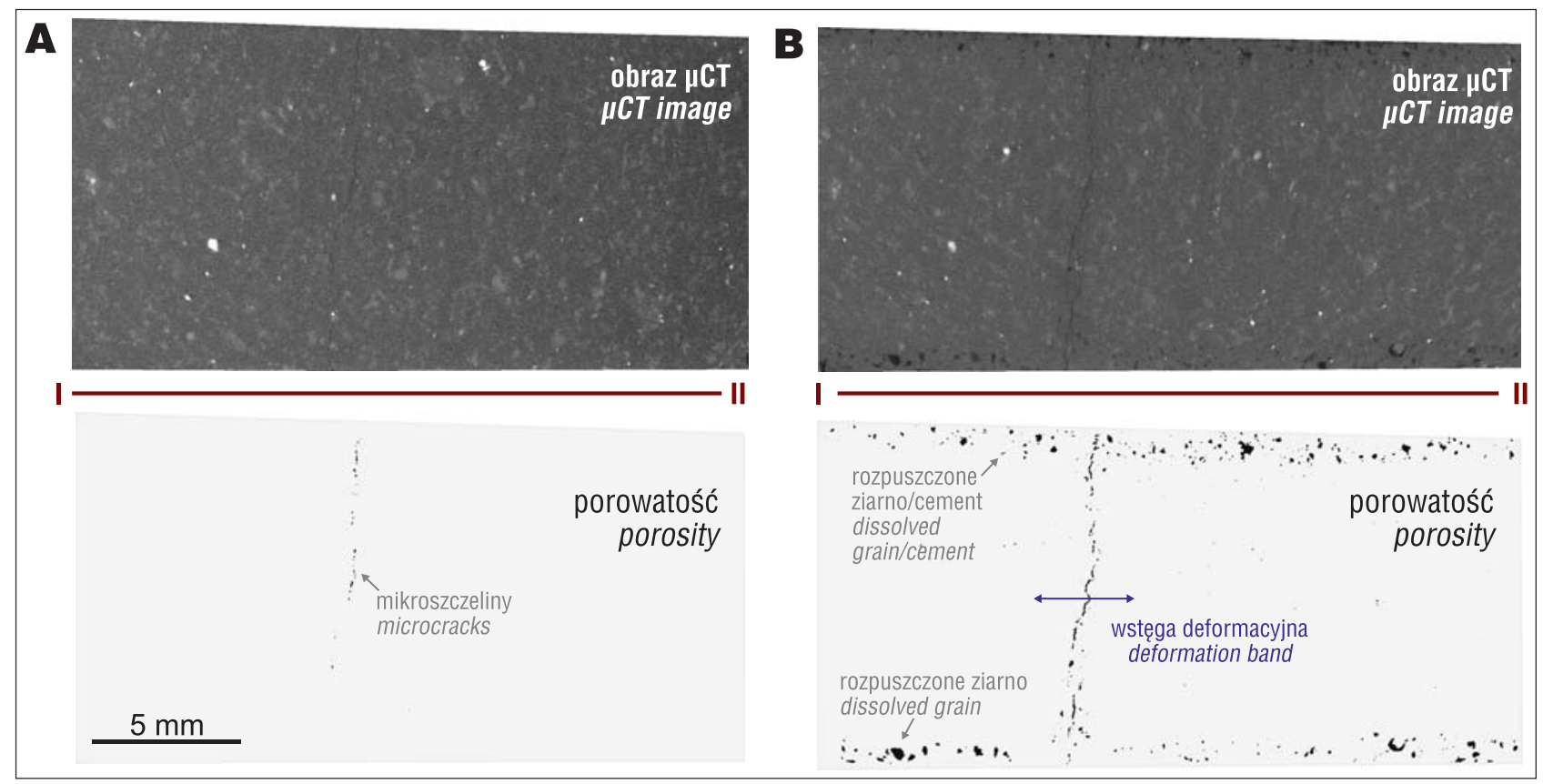

Ryc. 2. Przekrój próbki na obrazie $\mu \mathrm{CT}$ wraz z wyodrębnioną przestrzenią porową tego samego fragmentu skały: $\mathbf{A}$ - przed procesem kwasowania, B - po procesie kwasowania

Fig. 2. Cross-section of the sample in a $\mu \mathrm{CT}$ image and the corresponding extracted porosity: $\mathbf{A}$ - before acidizing, $\mathbf{B}$ - after acidizing of the sample. Images show the same rock fragment 


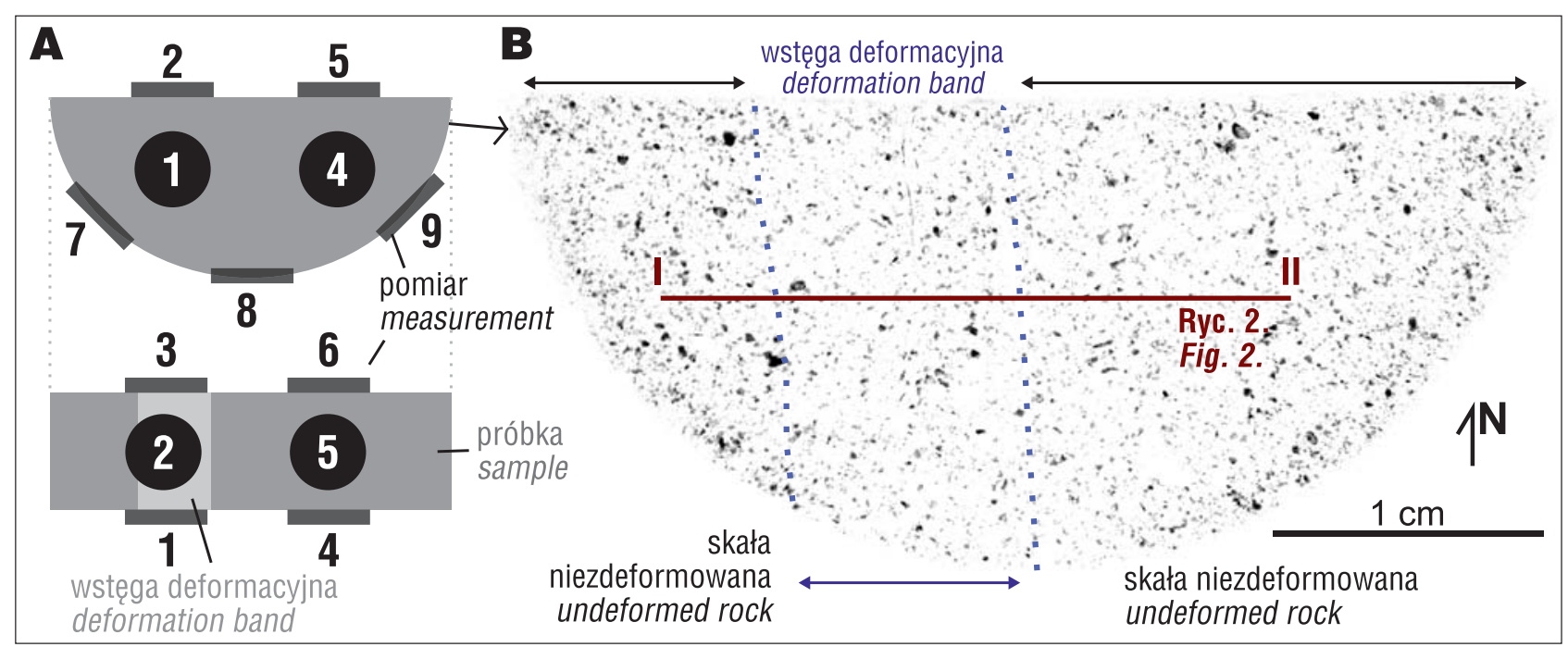

Ryc. 3. A - schemat pomiaru przepuszczalności na próbce skalnej, B - obraz $\mu \mathrm{CT}$ przestrzeni porowej (kolor czarny) z zaznaczonym przebiegiem wstęgi deformacyjnej

Fig. 3. A-scheme of permeability measurements on the rock sample, $\mathbf{B}-\mu \mathrm{CT}$ image of porous space (black colour) with deformation band marked

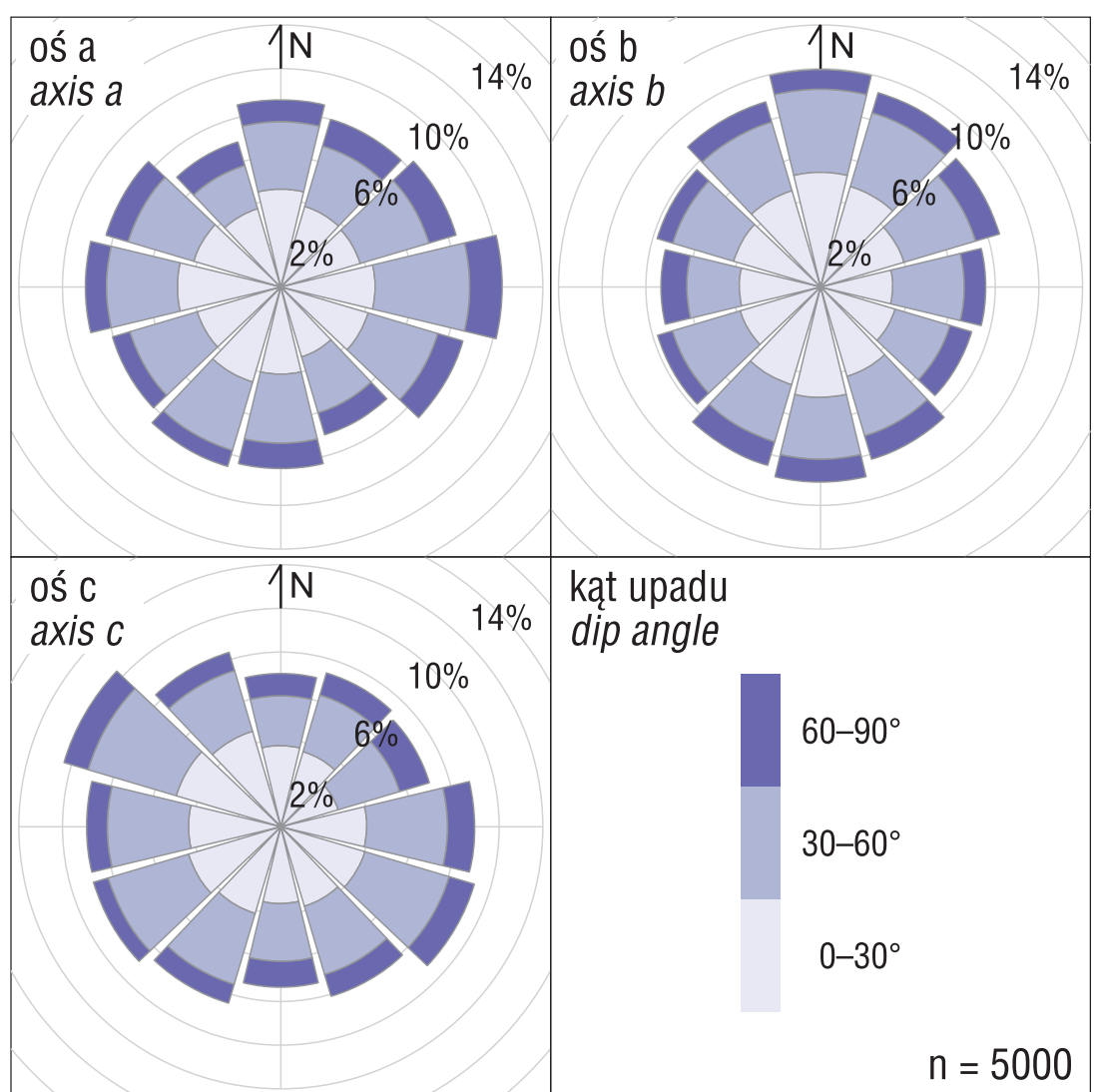

Ryc. 4. Diagram rozetowy ułożenia porów na podstawie dopasowanej elipsoidy o osiach a, b, c w lokalnym układzie odniesienia - tożsamy z ryc. 3

Fig. 4. Rose plot of spatial orientation of the voids based on ellipsoid fitting; a, b, cellipsoid axes. Projections in a local coordinate system, in accordance to that presented in Fig. 3

średnio o 2 pkt. procentowych do maksymalnie 4 (ryc. 4). Oś c stanowi normalną do powierzchni ab (wydłużenia) elipsoid.

Dominujące kąty upadu osi c należą do przedziału $0-30^{\circ}$ oraz $30-60^{\circ}$, co wskazuje, że pory (powierzchnie ab) w przeważającej mierze zapadają pod dużymi $\left(60-90^{\circ}\right)$ i umiarkowanymi $\left(30-60^{\circ}\right)$ kątami w stosunku do półcylindrycznej podstawy walca próbki. Zakres pomierzonej prze- puszczalności mieści się $\mathrm{W}$ przedziale 7,5 do $14,5 \mathrm{mD}$, natomiast porowatości waha się od 1,38 do 2,70\%. Obserwuje się wzrost przepuszczalności wraz ze wzrostem porowatości (ryc. 5).

Najwyższe wartości przepuszczalności są obserwowane wśród pomiarów obejmujących wstęgę deformacyjną (pomiary 1-3). Obserwuje się także zróżnicowanie wielkości przepuszczalności w zależności od kierunku pomiaru (pomiary 1-3). Pomiary $(1,3,4,6)$ wykonane prostopadle do półcylindrycznej podstawy próbki, czyli równolegle do najdłuższego wydłużenia porów, cechują się wyższą przepuszczalnością przy niższych zakresach porowatości w stosunku do pomiarów wykonanych równolegle do cylindrycznej podstawy próbki (ryc. 5).

\section{DYSKUSJA}

Zróżnicowanie parametrów zbiornikowych skały w badanej próbce wykazuje związek z obecnością struktury deformacyjnej oraz orientacją przestrzeni porowej. Uzyskane wyższe wartości przepuszczalności (obserwowane w miejscach występowania wstęg deformacyjnych) są związane z rozleglejszym systemem porów, który został uwidoczniony laboratoryjnie przez większy zasięg penetracji kwasu. Zwiększona penetracja kwasu w głąb skały w obrębie wstęgi jest efektem obecności sieci mikrospękań, którymi migracja kwasu zachodziła łatwiej. Badania pokazuja, że w obrębie struktur deformacyjnych mogą występować wydłużone pory zorientowane równolegle do struktur deformacyjnych. Takie ułożenie porów może przyczyniać się do wzrostu przepuszczalności mierzonej w kierunku równoległym do takich struktur (por. Farrell i in., 2014). Stosunkowo wysokie wartości przepuszczalności w odnie- 

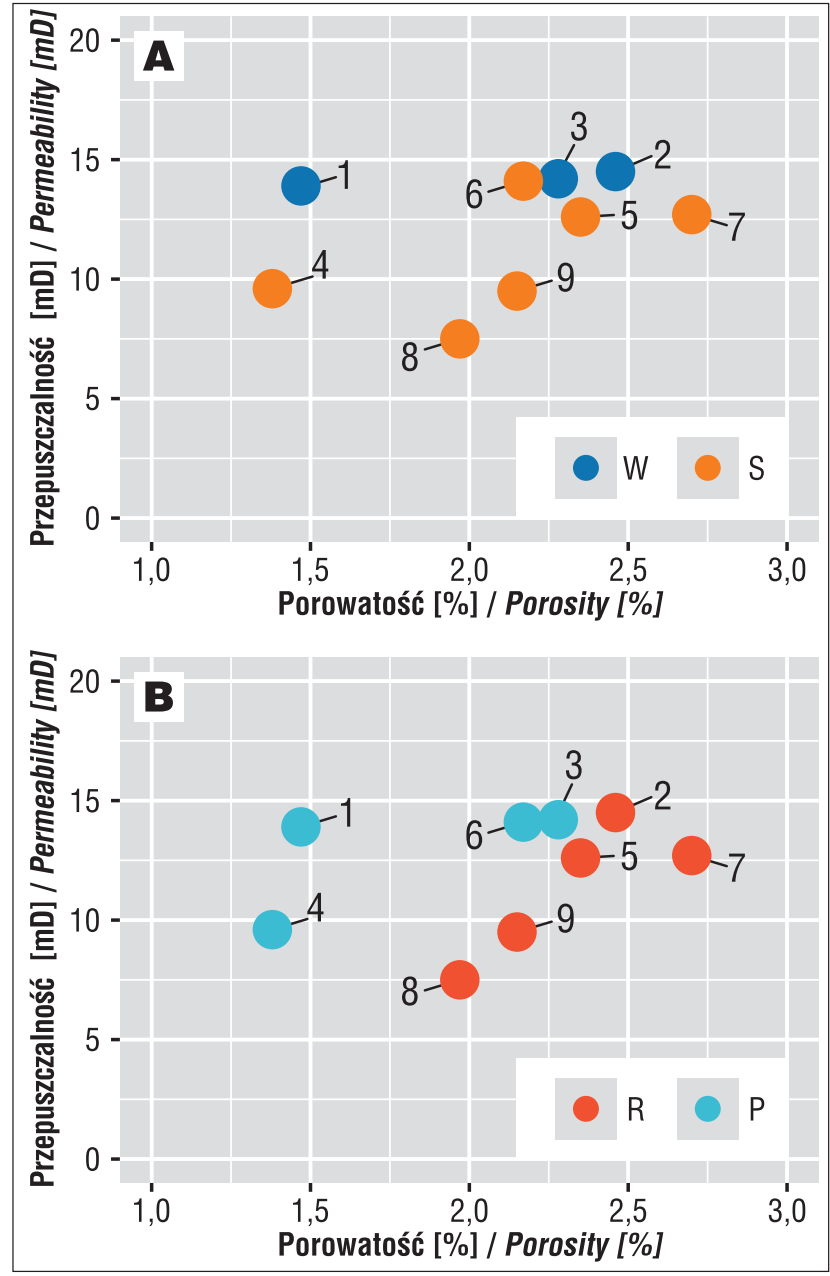

Ryc. 5. Zależność porowatości od przepuszczalności: A - w skale niezdeformowanej (S) oraz we wstędze deformacyjnej (W), B - z uwzględnieniem kierunku pomiaru: prostopadłym do podstawy walca $(\mathrm{P})$ oraz równoległym $(\mathrm{R})$. Numery nawiązują do miejsca pomiaru $\mathrm{z}$ ryc. $3 \mathrm{~A}$

Fig. 5. The relation between porosity and permeability: $\mathbf{A}-$ considering undeformed rock (S) and deformation band (W), B - considering the direction of the permeability measurement: perpendicular to the base of the sample cylinder $(\mathrm{P})$ and parallel to the base of the sample cylinder $(\mathrm{R})$. Numbers refer to the measurement number shown in Fig. 3A

sieniu do porowatości mogą być związane z powstałą po kwasowaniu siecią połączonych porów. Jednakże część powstałych porów może być niewidoczna na obrazie $\mu \mathrm{CT}$ ze względu na swój rozmiar, który jest poniżej rozdzielczości wykonanego zdjęcia. Na oboczność takich porów w badanej próbce wskazują także wyniki pomiaru porowatości metodą porozymetrii helowej. Względnie wysokie wartości przepuszczalności mogą mieć też związek ze sposobem jej pomiaru. Punktowe pomiary przepuszczalności obejmują tylko najbliższe otoczenie przyssawki urządzenia. Ponadto pomiary prowadzone na nieuszczelnionych rdzennikach są wyższe w porównaniu do pomiarów wykonywanych w tradycyjny sposób (por. Filomena i in., 2014). W przypadku anizotropii przepuszczalności obserwowanej w niezdeformowanej części skały najwyższe wartości przepuszczalności powinny być notowane w kierunku równoległym do ułożenia najdłuższych osi ziaren (Tiab, Donaldson, 2015). W nawiązaniu do analizowanej próbki, taka prawidłowość jest obserwowana w orientacji przestrzennej porów powstałych w procesie kwasowania. Pory te nawiązują do kierunku i ułożenia ziaren.

\section{WNIOSKI}

W świetle przedstawionych danych można stwierdzić, że:

- zastosowanie nowoczesnych technik obrazowania oraz punktowych pomiarów przepuszczalności pozwala na śledziennie zmian właściwości zbiornikowych w obrębie skał zbiornikowych w mikroskali;

- wykazano związek pomiędzy anizotropią przepuszczalności a mikroteksturą skały na przykładzie badanej próbki piaskowców krośnieńskich;

- stosowanie zabiegu kwasowania piaskowców krośnieńskich ze wstęgami deformacyjnymi może przyczynić się do polepszenia przepuszczalności tych skał oraz tworzenia dróg migracji w szczególności w obrębie wstęg deformacyjnych zawierających mikroszczeliny;

- badana próbka gruboziarnistych piaskowców krośnieńskich wykazuje najwyższą przepuszczalność w kierunku równoległym do najdłuższego wydłużenia porów.

Autorzy składają podziękowania recenzentom - Pani prof. Katarzynie Jarmołowicz-Szulc oraz Panu prof. Piotrowi Suchowi - za cenne wskazówki i konstruktywne uwagi. Badania przeprowadzono w ramach projektu $\mathrm{nr}$ 2018/31/N/ST10/02486 finansowanego przez Narodowe Centrum Nauki.

\section{LITERATURA}

BEARD D.C., WEYL P.K. 1973 - Influence of Texture on Porosity and Permeability of Unconsolidated Sand. Am. Assoc. Pet. Geol. Bull., 57: 349-369.

FARRELL N.J.C., HEALY D., TAYLOR C.W. 2014 - Anisotropy of permeability in faulted porous sandstones. J. Struct. Geol., 63: 50-67.

FILOMENA C.M., HORNUNG J., STOLLHOFEN H. 2014 - Assessing accuracy of gas-driven permeability measurements: A comparative study of diverse Hassler-cell and probe permeameter devices. Solid Earth, 5: $1-11$.

FOSSEN H., SOLIVA R., BALlAS G., TRZASKOS B., CAVALCANTE C., SCHULTZ R.A. 2018 - A review of deformation bands in reservoir sandstones: geometries, mechanisms and distribution. Geol. Soc. Spec. Publ., 459: 9-33.

QU D., TVERANGER J. 2017 - Incorporation of deformation band fault damage zones in reservoir models. Am. Assoc. Pet. Geol. Bull., 101: 423-443.

STRZELECKI P.J., FHEED A., RADZIK N., ŚWIERCZEWSKA A. 2019 - Wykorzystanie rentgenowskiej mikrotomografii komputerowej i cyfrowej analizy obrazu do petrologicznej charakterystyki skał węglanowych. Prz. Geol., 67: 195-197.

STRZELECKI P.J., ŚWIERCZEWSKA A., KOPCZEWSKA K., FHEED A., TARASIUK J., WROŃSKI S. 2021 - Decoding rocks: an assessment of geomaterial microstructure using X-ray microtomography, image analysis and multivariate statistics. Materials, 14 (12): 3266.

TIAB D., DONALDSON E.C. 2015 - Petrophysics: Theory and Practice of Measuring Reservoir Rock and Fluid Transport Properties. Gulf Professional Publishing.

Praca wpłynęła do redakcji 15.04.2021 r.

Akceptowano do druku 24.06.2021 r. 